\title{
Pembelajaran Diversifikasi Produk Olahan Bagi Pengrajin Emping Melinjo
}

\author{
Entoh Tohani ${ }^{\text {1) }}$, Hiryanto ${ }^{2)}$, RB. Suharta ${ }^{3)}$, lis Prasetyo ${ }^{4)}$ \\ Pendidikan Nonformal, Universitas Negeri Yogyakarta \\ tohani@uny.ac.id*, hiryanto@uny.ac.id,rbsuharta@uny.ac.id, iis.prasetyo@uny.ac.id
}

\begin{abstract}
Abstrak
Penelitian ini bertujuan mengembangkan kemampuan diversifikasi produk olahan berbasis potensi local bagi perempuan pengrajin emping melinjo sebagai upaya untuk memberdayaan kelompok dan warga masyarakat. Kemampuan diversifikasi ini perlu dikembangkan karena kelompok belum mampu mengembangkan produk bernilai jual tinggi dan meningkatkan kebermanfaatan usaha kelompok. Penelitian ini merupakan penelitian tindakan dengan tahapan pengkajian isu, perencanaan, pengimplementasian tindakan, dan refleksi. Tindakan berupa pembelajaran vokasional kepada para anggota kelompok di Desa Kalirejo,Kulon Progo. Data dikumpulkan dengan wawancara dan observasi dan dianalisis secara kualitatif yaitu direduksi, disajikan dan ditarik kesimpulan. Teknik keabsaha data dilakukan dengan pengamatan perpanjangan dan triangulasi. Hasil penelitian menunjukkan bahwa tindakan yang diberikan kepada kelompok sasaran memberikan perubahan positif berupa mereka dapat memiliki kesadaran untuk lebih inovatif dan memiliki pengetahuna dan keterampilan dalam produksi diversifikasi produk olahan berbasis potensi local. Oleh karenanya, tindakan berkesimbungan dan relevan perlu dilaksanakan kembali di masa depan dengan menyediakan fasilitas yang memadai.
\end{abstract}

Kata kunci: pembelajaran, diversifikasi, perempuan, produk

\section{Abstract}

This study aimed to develop the ability to diversify processed products based on local potential for women "emping melinjo" craftsmen in an effort to empower groups and community members. This diversification ability needs to be developed because the group has not been able to develop high-value-selling products and increase the usefulness of group businesses. This research was an action research with the stages of the study of issues, planning, implementing actions, and reflection. The action was in the form of vocational learning to group members in Kalirejo Village, Kulon Progo. Data collected by interview and observation and analyzed qualitatively that is reduced, presented and drawn conclusions. The validity of the data was done by observing the extension and triangulation. The results showed that the actions given to the target group gave positive changes in the form they could have an awareness to be more innovative and have knowledge and skills in the production of diversified products based on local potential. Therefore, relevant and relevant actions need to be implemented again in the future by providing adequate facilities.

Keywords: learning, diversification, women, products 


\section{PENDAHULUAN}

Desa Kalirejo merupakan salah
satu desa yang berada wilayah
Kecamatan Kokap, Kabupaten Kulon
Progo, Daerah Istimewa Yogyakarta.
Desa ini terletak di bagian lereng selatan
perbukitan Menoreh dengan ketinggian
tanah mencapai 6oo meter di atas
permukaan laut. Luas desa ini mencapai
12.951.50o ha yang sebagian besar berupa
tanah kering. Wilayah desa ini
dimanfaatkan untuk berbagai
kepentingan antar lain secara umum sebagai pekarangan dan bangunan seluas 11.927.500 ha, untuk perladangan seluas 7.350 ha dan sisanya dipergunakan untuk pasar, kuburan dan jalan. Jumlah penduduk Desa Kalirejo pada tahun 2017 mencapai 4.211 jiwa dengan perincian laki-laki 2.121 jiwa dan perempuan 2.090 jiwa. Dilihat dari kelompok umur, penduduk dewasa berjumlah 1.650 laki-laki dan 1.670 penduduk perempuan, dan kelompok anak berjumlah 420 laki-laki dan 470 perempuan (BPS, 2018).

Dilihat dari tingkat pendidikan penduduk, mayoritas penduduk desa Kalirejo sudah menamatkan jenjang pendidikan menengah yaitu sebanyak 1.186 orang menempuh pendidikan jenjang SLTP, dan 1.075 orang menempuh jenjang SLTA, dan baru 124 orang yang menempuh pendidikan jenjang diploma dan sarjana. Sebanyak 406 anak belum menempuan pendidikan anak usia dini, sebanyak 115 anak sudah menempuh pendidikan anak usia dini, dan sisanya adalah mereka yang belum/tidak pernah sekolah dan tidak dapat membaca dan menulis huruf latin. Dilihat dari aspek ekonomi, pekerjaan mayoritas penduduk desa ini adalah sebagai petani yang berjumlah 2.16o orang, sebagai buruh mencapai 311 orang, wirausaha 302 orang disusul dengan warga masyarakat yang menjadi wirausaha, ibu rumah tangga mencapai 374 orang dan pekerja harian lepas mencapai 267 orang (Monografi Desa Kalirejo, 2017).

Terkait dengan aktivitas ekonomi, jumlah warga yang bekerja di sektor petani khususnya petani perkebunan yang cukup banyak tersebut, tidak lepas dari letak georgafis Kalirejo yang mana wilayah desa ini merupakan daerah pegunungan Menoreh yang memamerkan keindahan alam yang masih alami dan mengadung sumber daya alam yang melimpah. Sebagai wilayah pegunungan, wilayah ini memiliki potensi yang baik berupa tumbuh dengan subur pohon-pohon kelapa sebagai potensi alam yang sangat melimpah. Akibatnya, tidak heran, mayoritas pekerjaan masyarakat sebagai penderes nira kelapa. Kegiatan menderes dilakukan setiap hari oleh para penduduk baik di musim kemarau maupun di musin penghujan. Potensi berupa hasil bumi seperti umbi-umbian, ketela, dan tanaman obat pun banyak ditemukan dan dibudidayakan di wilayah ini. Potensi lain adalah sektor perkebunan kayu jati, sengon, yang menjadi milik penduduk untuk dijadikan salah satu sumber penghasilan ekonomi dan rumpun pohon bambu yang tersedia banyak di wilayah ini yang semestinya digunakan selain untuk bahan bangunan dan dapat dijadikan beragam kerajian. Desa Kalirejo pun memiliki panorama pegunungan yang asri dan alami sehingga dapat di manfaatkan sebagai daerah wisata sehingga dapat menambah pendapatan masyarakat. 
Selain potensi ekonomi yang melimpah, Desa Kalirejo memiliki masalah yang serius untuk diatasi. Desa ini merupakan salah satu desa yang berada di Kecamatan Kokap Kulon Progo yang tergolong pada wilayah yang berpotensi bencana alam cukup tinggi. Hasil penelitian menunjukkan bahwa desa ini memiliki karakteristik geografi yang merupakan dataran tinggi dengan resiko bencana alam mencakup tanah longsor, kekeringan, angin kencang, wabah penyakit, dan kecelakaan kerja (Entoh, Lutfi, \& Nur Djazifah, 2017). Kejadian bencana tersebut telah menyebabkan kerugian kepada masyarakat seperti kehilangan harta benda, rumah, bahkan jiwa.

Salah satu upaya yang dilakukan
untuk memberdayakan kaum perempuan di desa Kalirejo yang notabene desa rawan bencana dan mereka berperan sebagai para isteri penderes nira kelapa agar menjadi produktif secara ekonomi adalah dengan membentuk usaha kelompok produksi emping melinjo yang bernama kelompok "Mekar Kusuma" dengan sekretariatnya berada di dusun Sengir. Usaha emping melinjo diselenggarakan atas dasar pertimbangan bahwa banyak terdapat potensi alam berupa pohon melinjo yang ada lingkungan sekitar namun belum dimanfaatkan secara baik menjadi produk yang bernilai ekonomi karena warga masyarakat belum memiliki kemampuan mengolahnya. Inisiator dari usaha kelompok emping melinjo ada pemerintahan desa setempat dan bekerja sama dengan Universitas Negeri Yogyakarta melalui pelaksaan program tri dharma perguruan tingginya (Tohani, dkk, 2018). Kelompok usaha ekonomi produktif ini sudah berjalan sekitar satu tahun dengan jumlah anggota sebanyak 25 orang perempuan dengan usia yang masih produktif. Mereka terlibat dalam kelompok didasarkan pada pandangan dan motivasi yang sama yaitu menginginkan perubahan kualitas kehidupan ekonomi keluarga yang mana selama ini mereka mengandalkan penghasilan suami sebagai penderes nira kelapa. Kelompok ini dalam perkembangannnya memiliki struktur organisasi yang sudah relative ajeg yaitu seorang ketua, seorang bendahara, dan seorang sekretaris dengan masingmasing tugasnya. Pengelolaan kelompok usaha ini menekankan pada nilai-nilai kekeluargaan misalnya saling membantu dalam pemasaran, mencari bahan baku melinjo, dan kerja sama dalam proses pembuatan emping melinjo.

Proses produksi pembuatan emping oleh kaum perempuan dimaksud relative berjalan dengan baik. Produksi dilakukan tiga kali dalam seminggu secara rutin baik terdapat pesanan maupun tidak terdapat pesanan. Dalam produksi emping melinjo, sistem bergilir dalam pengerjaan emping diterapkan oleh kelompok sehingga semua anggota dapat mengerjakan produksi emping dengan frekuensi keterlibatan yang sama. Sedangkan output produksi berupa emping melinjo dipandang terus terjadi peningkatan kuantitas dalam satu tahun terakhir ini. Sampai sekarang diperkirakan lebih dari 3 kwintal emping melinjo dapat diproduksi oleh anggota kelompok. Produk ini dipasarkan baik kepada masyarakat sekitar maupun ke toko-toko yang ada di wilayah kecamatan Kokap secara langsung oleh para anggota kelompok. Pemasaran produk tidak mengalami kendala yang 
Diklus: Jurnal Pendidikan Luar Sekolah, 2 (3), September 2019 - 73

Entoh Tohani, Hiryanto, RB. Suharta, Iis Prasetyo

berarti artinya produk dapat diserap oleh pasar.

Keberadaan kelompok dipandang suatu anugerah bagi para anggotanya. Mereka menyadari bahwa walau masih dalam usia muda, hasil kegiatan ekonomi ini dipandang bermanfaat yaitu mampu memberikan pemasukan pendapatan ekonomi keluarga dan membangun semangat untuk maju bagi para anggotanya. Namun demikian, kelompok usaha ini tidak lepas dari masalah yang dihadapi. Menurut ketua kelompok, aktivitas produksi sering terganggu oleh kegiatan lain para anggota seperti aktivitas pirukunan yang berkembang di masyarakat berupa kegiatan rewangan, sripah, jagong, dan lainnya. Hambatan ini dirasa merugikan terutama pada saat bahan baku berupa melinjo mentah sudah menumpuk sehingga dapat menurunkan kualitas produk apabila tidak segera diproses. Kendala lain adalah apabila musim penghujan, proses pengeringan emping melinjo terganggu sehingga menyebabkan kualitas emping tidak bisa maksimal misalnya muncul jamur dan kandungan air dalam emping cukup tinggi. Masalah lain yang dihadapi kelompok adalah harga emping melinjo dalam bentuk emping mentah sering tidak stabil. Apabila di pasar penawaran emping tinggi seiring dengan musim melinjo maka harga jual emping yang diproduksi kelompok pun mengalami penurunan sehingga menyebabkan keuntungan yang didapat menurun (Wawancara, 26/1/209). Terhadap masalah-masalah ini, kelompok membutuhan solusi yang dapat menjaga produktivitas usaha agar tetap terjaga.

Permasalahan yang dihadapi tersebut di atas, tidak lepas dari kemampuan memproduksi emping melinjo semata yang selama ini mereka kuasai. Mereka menyadari bahwa untuk mengoptimalkan kinerja kelompok dibutuhkan kemampuan untuk memproduksi bukan hanya produk dalam satu bentuk/variasi namun dalam bentuk yang beragam sehingga dapat menembus pasar yang berbeda-beda. Hal ini dikemukakan oleh Ketua Kelompok yang dikuatkan oleh Bendahara kelompok bahwa mereka menginginkan pembinaan untuk mengolah produk olahan berbahan melinjo agar menjadi produk yang beraneka ragam dan memiliki nilai ekonomi tinggi. Kemampuan kaum perempuan saat ini masih terbatas pada proses produksi emping melinjo dalam bentuk tunggal yaitu berupa emping mentah siap jual yang menyebabkan penghasilan yang diperoleh belum optimal. Oleh karenanya, kompetensi kaum perempuan dalam memproduksi beragam (diversifikasi) produk olahan berbahan melinjo perlu dikembangkan melalui proses pendidikan dan pelatihan bermakna agar mereka menjadi lebih produktif dalam berusaha dan meningkatkan kesejahteraan ekonominya.

Kelompok ekonomi produktif kaum perempuan merupakan suatu wahana untuk mengembangkan kesejahteraan ekonomi warga masyarakat melalui pelaksanaan kegiatan usaha proses produksi barang/jasa bernilai ekonomi, dan kegiatan lain yang mendukung pencapaian tujuan organisasi. Kehadiran kelompok usaha ekonomi produktif dapat disebabkan oleh factor penyebabnya yaitu terdapat masalah yang dihadapi bersama misalnya kemiskinan, pengangguran, dan 


\section{Diklus: Jurnal Pendidikan Luar Sekolah, 2 (3), September 2019 - 74 \\ Entoh Tohani, Hiryanto, RB. Suharta, Iis Prasetyo}

keterbatasan lapangan kerja, dukungan pemberdayaan yang dilakukan oleh lembaga atau pemerintah, dan adanya keinginan untuk melakukan perubahan agar mencapai kehidupan yang lebih baik.

Kelompok ekonomi produktif memiliki tujuan membentuk para anggotanya menjadi sejahtera khususnya dalam aspek ekonomi. Keterlibatan para anggota dalam aktivitas kelompok diharapkan menjadikan mereka mampu meningkatkan pendapatan dan penghasilan guna memenuhi kebutuhan hidup diri sendiri, keluarga, bahkan masyarakat. Pencapaian tujuan ini sangat tergantung oleh kinerja lembaga dimaksud yang mencakup produktivitas, efektivitas, dan akuntabilitas organisasi. Sebuah organisasi yang berkinerja baik ditandai dengan adanya kemimpinan yang kolaboratif, memiliki rencana program dan strategis yang baik, membangun tim kerja yang solid, terjadi pengembangan sumber daya manusia, terjadi proses komunikasi yang humanis, menciptakan kenyamanan dalam bekerja, dan tercipta budaya organisasi yang kondusif. Hal yang sangat penting dalam menentukan keberhasilan kelompok ekonomi produktif adalah kualitas sumber daya manusia (human capital) yang dimilikinya.

Human capital dapat dimaknai sebagai potensi yang dimiliki seseorang yang mencakup the knowledge, skills, abilities and capacity to develop and innovate possessed by people in an organization (Becker, 1994). Lebih lanjut dikemukakan Bontis et all (1999) bahwa: Human capital represents the human factor in the organization; the combined intelligence, skills and expertise that gives the organization its distinctive character. The human elements of the organization are those that are capable of learning, changing, innovating and providing the creative thrust which if properly motivated can ensure the long-term survival of the organization (Baron \& Amstrong, 2007).

Mengacu pada pengertian di atas, dapat dipahami bahwa kapasitas inovasi harus dimiliki oleh individuindividu yang ada dalam organisasi. Salah satunya adalah kapasitas inovasi dalam mengembangkan produk/jasa, selain terkait dengan pengembangan proses, lingkungan dan manajerial. Perwujudan kapasitas inovasi ini dapat terlihat dari dihasilkan produk yang dapat menembus pasar baru, memperkuat pangsa pasar yang ada, atau mendukung produk yang ada. Kapasitas inovasi ini menjadi alat untuk mencapai peluang yang terdapat di masyarakat dan sekaligus memenangkan persaingan dalam memperoleh sumber daya yang dbutuhkan.

Karena pentingnya kapasitas inovasi produk/jasa dibentuk dan dikembangkan bagi para anggota kelompok usaha produktif, maka upaya pemberdayaan perlu dilakukan secara terarah baik secara internal oleh kelompok sendiri dengan mengembangkan perilaku belajar dalam kehidupan berorganisasi, dan secara eksternal dengan cara memberikan pendidikan, pembelajaran, atau aktivitas edukatif lain yang diselenggarakan oleh pihak eksternal. Sebagaimana dipahami bahwa pemberdayaan kelompok ekonomi produktif pada dasarnya adalah 


\section{Diklus: Jurnal Pendidikan Luar Sekolah, 2 (3), September 2019 - 75 \\ Entoh Tohani, Hiryanto, RB. Suharta, Iis Prasetyo}

memberikan "power" agar individuindividu atau kelompok menjadi lebih berdaya. Terkait dengan ini, Narayan (2002) menjelaskan bagaimana proses pemberdayaan dalam bidang ekonomi khususnya bagi kelompok ekonomi produktif dengan titik berat pada peningkatan kapasitas organisasi harus dilakukan seperti gambar berikut:

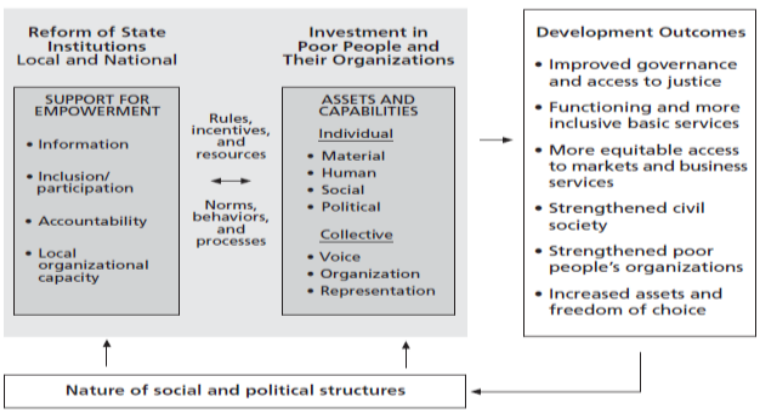

Gambar 2 Kerangka logis pemberdayaan (Narayan, 2002)

Secara detail proses pengembangan kapasitas inovasi produk dapat dilakukan dengan melakukan berbagai tindakan pendidikan yang berorientasi pada pemaknaan kembali pengalaman yang dimiliki individu seperti melakukan pelatihan dan pendidikan, mengembangkan belajar swa-arah (self-directed learning), mentoring/apprenticeship, pelatihan induksi, dan pendidikan formal, bahkan untuk mengembangkan kapasitas kelembagaan dapat dilakukan dengan cara mengelola pengetahuan/informasi (knowledge management) yang memungkinkan terjadi perolehan keinovasian (Müller, et all., 2015).

Mendasarkan pada pemikiran di atas, dipandang perlu melakukan penelitian yang diarahkan pada mengembangkan kualitas kehidupan ekonomi keluarga dan masyarakat, melalui tindakan pemberdayaan kaum perempuan di Kalirejo sebagai desa rawan bencana melalui pendidikan kecakapan hidup vokasional berbasis potensi lokal agar mereka mampu berkontribusi dengan memberikan manfaat ekonomi, sosial, dan politik yang bermakna terhadap kehidupan bermasyarakat.

\section{METODE}

Penelitian ini menggunakan pendekatan action research yang dimaksudkan untuk mengembangkan kemampuan diversifikasi olahan produk berbasis potensi local bagi kaum perempuan pengrajin emping melinjo. Model penelitian tindakan yang digunakan adalah model penelitian tindakan partisipatoris yang menekankan para kemitraan pada proses pembelajaran atau pengembangan masyarakat. Pelaksanaan kegiatan bersifat siklis/spiral yaitu: memahami isu/masalah, merencanakan tindakan, mengimplementasikan tindakan dan merefleksi untuk memperbaiki rencana tindakan (McIntyre, 2007). Dalam penelitian ini, tindakan dilakukan dalam sekali siklus penelitian.

Pengumpulan data dilakukan dengan wawancara dan observasi sesuai dengan pelaksanaan pada masingmasing tahapan penelitian tindakan dimaksud. Wawacara dilakukan kepada kepala desa, kepala dusun, kader pemberdayaan masyarakat, ketua kelompok emping melinjo, dan beberapa anggota kelompok emping melinjo. Pengumpulan data dilakukan oleh peneliti bekerja sama dengan ketua kelompok emping melinjo. Data dianalisis dengan menggunakan tekni analisis kualitatif dan menekankan pada 
refleksi bersama peneliti dan kelompok sasaran.

Penelitian tindakan ini dilakukan pada Bulan Juni sampai dengan Agustus 2019 dengan lokasi Desa Kalirejo Kecamatan Kokap Kabupaten Kulon Progo. Partisipan penelitian ini sebanyak 25 perempuan yang tergabung dalam kelompok produksi emping melinjo "MK". Pemilihan kelompok sasaran ini didasarkan pada keberadaan mereka yang aktif dalam mengembangkan kualitas kehidupan masyarakat di desa tersebut. Penentuan partisipan penelitian dilakukan secara langsung dengan mempertimbangkan kesediaan, ketersediaan waktu partisipan dan waktu pelaksanaan

\section{HASIL DAN PEMBAHASAN}

Hasil penelitian sebagaimana tujuan penelitian yaitu bagaimana mengembangkan kemampuan kelompok sasaran dalam diversifikasi produk olahan berbasis potensi local dapat dikemukakan di bawah ini dengan tahapan persiapan, pelaksanaan, dan evaluasi.

\section{Analisis masalah/isu}

Analisis masalah atau isu dilakukan dengan diskusi dengan para pihak terkait yang terlibat langsung dalam kelompok usaha emping melinjo. Dalam hal ini, peneliti melakukan diskusi terfokus mendalam dengan ketua dan beberapa anggota kelompok emping melinjo mengenai keberlangsung usaha yang mereka geluti. Hasil diskusi yang berfokus pada pengolahan produk olahan emping melinjo menunjukkan bahwa kelompok belum dapat melakukan upaya pengembangan produk karena mereka belum dapat memproduksi produk yang memiliki nilai jual yang lebih tinggi. Menurut ketua kelompok, Rhm, kelompok hanya memproduksi emping dalam bentuk mentah yaitu emping mentah berasa original, dan belum memiliki kemampuan mengembangkan produk yang beragam seperti emping melinjo beraneka rasa. Mereka menyadari kebutuhan pengembangan usaha harus didukung dengan kepemilikan kemampuan berinovasi yang menghasilkan diversiifikasi produk kelompok yang diterima masyarakat. Melalui diskusi tersebut dihasilkan pula suatu pemikiran bagaimana tindakan mengembangkan kemampuan diversifilasi produk yang dapat dilakukan sesuai sumber daya yaitu tindakan pembelajaran peningkatan kemampuan diversifikasi produk olahan berbasis potensi local sebagai upaya meningkatkan produktivitas kelompok usaha.

\section{Perencanaan}

Tindakan edukatif untuk peningkatan kemampuan diversifikasi produk olahan berbasis produk yang direncanakan bersama peneliti dan kelompok sasaran ditampilkan dalam table 1. Persiapan lain untuk melakukan kegiatan pendidikan ini pun dilakaukan terkait dengan hal-hal teknis yang mendukung pelaksanaan kegiatan pengembangan kelompok sasaran agar dapat berhasil seperti seminar instrument penelitian, koordinasi dengan perwakilan kelompok sasaran dan tokoh masyarakat setempat/pihak terkait, komunikasi informal dengan narasumber teknis pengembangan, mempelajari karakteristik kelompok sasaran, pengurusan perijinan, penyusunan bahan ajar, dan sebagainya. 
Diklus: Jurnal Pendidikan Luar Sekolah, 2 (3), September 2019 - 77

Entoh Tohani, Hiryanto, RB. Suharta, Iis Prasetyo

Tabel 1 Rencana pembelajaran diversifikasi produk

\begin{tabular}{|c|c|c|c|c|}
\hline Waktu/Sesi & Materi & Tujuan & Metode & Pelaksana \\
\hline Pertemuan 1 & Penyadaran & $\begin{array}{l}\text { - Membangun kesadaran kelompok } \\
\text { sasaran akan pentingnya pendidikan dan } \\
\text { pelatihan diversifikasi produk olahan } \\
\text { - Membangun kesepakatan dan komitmen } \\
\text { bersama dalam kegiatan pelaksanaan } \\
\text { pendidikan dan pelatihan bagi kelompok } \\
\text { sasaran }\end{array}$ & Ceramah & $\begin{array}{l}\text { Peneliti } \\
\text { Kelompok } \\
\text { sasaran }\end{array}$ \\
\hline Pertemuan 2 & $\begin{array}{l}\text { Pembelajaran } \\
\text { inovaasi produk }\end{array}$ & $\begin{array}{l}\text { Memberikan sikap, pengetahuan dan } \\
\text { keterampilan kepada kelompok sasaran } \\
\text { mengenai: a) urgensi inovasi produk } \\
\text { olahan dalam peningkatan ekonomi, dan } \\
\text { b) proses identifikasi kebutuhan } \\
\text { diversifikasi dan inovasi produk olahan } \\
\text { yang dihasilkan kelompok sasaran }\end{array}$ & $\begin{array}{l}\text { Ceramah } \\
\text { dan Diskusi }\end{array}$ & $\begin{array}{l}\text { Peneliti } \\
\text { Kelompok } \\
\text { sasaran }\end{array}$ \\
\hline Pertemuan 3 & $\begin{array}{l}\text { Pembelajaran } \\
\text { teori: } \\
\text { pengolahan } \\
\text { diversitifikasi } \\
\text { olahan emping }\end{array}$ & $\begin{array}{l}\text { - Memberikan sikap, pengetahuan dan } \\
\text { keterampilan kepada kelompok sasaran } \\
\text { dalam hal memproduksi beragam produk } \\
\text { bernilai ekonomis }\end{array}$ & $\begin{array}{l}\text { Ceramah } \\
\text { Diskusi }\end{array}$ & $\begin{array}{c}\text { Narasumber } \\
\text { Kelompok } \\
\text { sasaran } \\
\text { Peneliti }\end{array}$ \\
\hline Pertemuan 4 & $\begin{array}{l}\text { Pembelajaran } \\
\text { praktik } \\
\text { pengelolaan }\end{array}$ & $\begin{array}{l}\text { - Memberikan nilai, pengetahuan dan } \\
\text { keterampilan memproduksi, mengemas, } \\
\text { dan memasarkan beragam produk olahan } \\
\text { - Memberikan pengetahuan dan } \\
\text { keterampilan dalam memasarkan } \\
\text { beragam produk olahan baru bernilai } \\
\text { ekonomi kepada pasar }\end{array}$ & $\begin{array}{l}\text { Penugasan } \\
\text { berbasis } \\
\text { pengalaman } \\
\text { Diskusi }\end{array}$ & $\begin{array}{l}\text { Narasumber } \\
\text { Kelompok } \\
\text { sasaran } \\
\text { Peneliti }\end{array}$ \\
\hline Pertemuan 5 & $\begin{array}{l}\text { Penugasan } \\
\text { produksi }\end{array}$ & $\begin{array}{l}\text { - Memberikan nilai, pengetahuan dan } \\
\text { keterampilan memproduksi, mengemas, } \\
\text { dan memasarkan beragam produk olahan } \\
\text { - Memberikan pengetahuan dan } \\
\text { keterampilan dalam memasarkan } \\
\text { beragam produk olahan baru bernilai } \\
\text { ekonomi kepada pasar }\end{array}$ & $\begin{array}{l}\text { Praktik } \\
\text { mandiri }\end{array}$ & $\begin{array}{l}\text { Peneliti } \\
\text { Kelompok } \\
\text { sasaran }\end{array}$ \\
\hline Pertemuan 6 & Reflesi bersama & $\begin{array}{l}\text { - Mengetahui capaian perubahan perilaku } \\
\text { kelompok sasaran sebagai hasil belajar } \\
\text { yang diperoleh } \\
\text { - Membangun kesepahaman dan } \\
\text { komitmen kelompok sasaran untuk } \\
\text { menerapkan hasil belajar }\end{array}$ & Ceramah & $\begin{array}{l}\text { Peneliti } \\
\text { Kelompok } \\
\text { sasaran }\end{array}$ \\
\hline
\end{tabular}




\section{Diklus: Jurnal Pendidikan Luar Sekolah, 2 (3), September 2019 - 78 \\ Entoh Tohani, Hiryanto, RB. Suharta, Iis Prasetyo}

\section{Pelaksanaan Pelatihan}

Kegiatan pelatihan dilakukan dengan kegiatan pembelajaran bertempat di ruang pertemuan dusun Sengir, Kalirejo, Kokap. Pembelajaran dilakukan dengan mekanisme antara lain: (a) penyadaran kepada warga belajar, (b) orientasi warga belajar dan penyampaian materi urgensi produk olahan, (c) penyampaian materi diversifikasi olahan produk, (d) penyampaian materi mengenai diversifikasi olahan produk, (e) pelaksanaan evaluasi bersama, dan ( $\mathrm{f}$ ) praktik mandiri.

Pertama, orientasi warga belajar dilakukan dengan tujuan memberikan memberikan sikap, pengetahuan dan keterampilan kepada kelompok sasaran mengenai urgensi inovasi produk olahan dalam peningkatan ekonomi. Penyampaian materi dilakukan oleh tim pengabdi, dengan metode ceramah dan diskusi. Narasumber memberikan penjelasan mengenai pentingnya ugensi poduk emping sebagai unggulan kelompok untuk dikreasi menjadi produk yang lebih memiliki nilai tambah. Menurut narasumber, adanya olahan produk akan meningkatkan pangsa pasar dan memungkinkan pemasaran menjadi lebih luas sehingga berpeluang meningkatkan penjualan dan penghasilan. Untuk menghasilkan olahan produk, warga belajar diajak untuk memahami bagaimana selera konsumen terhadap produk yang ada. Menurutnya narasumber produk emping sebagai produk andalan kelompok memiliki peluang besar untuk dikreasikan. Hal ini dikarenakan masyarakat memiliki karakteristik sosial budaya yang menjanjikan untuk pemasaran produk olahan seperti kenduri, selamatan, merti dusun, dsb. Ditegaskan pula, untuk menghasilkan produk inovatif, warga belajar harus memiliki komitmen dan motivasi tinggi untuk mencoba berkreasi dan memasarkannya ke masyarakat. Mereka harus memiliki nilai-nilai wirausaha seperti berani ambil resiko, selalu mencoba hal baru, dan tidak mudah menyerah. Dalam sesi pembelajaran ini, warga belajar memperhatikan apa yang disampaikan oleh narasumber dalam suasana hangat, dan terkadang diselengi riuh senda gurau.
Kedua, pembelajaran teori mengenai diversifikasi olahan produk melinjo. Pembelajaran materi disampaikan oleh praktisi yang memiliki pengalaman dalam berusaha emping melinjo. Dalam pembelajaran ini, praktisi memberikan penjelasan mengenai peluang usaha diversifikasi emping melinjo. Ia menjelaskan bagaimana produk diversifikasi yang dihasilkannya dapat diterima di pasar. Menggunakan pengalaman yang dimiliknya, ia memberikan contoh bagaimana manfaat hasil penjualan produk olahan dapat meningkatkan produktivitas penjualan. Menurutnya, produk olahan emping melinjo yang menimal dibuat dalam emping aneka rasa seperti rasa asing, rasa manis-asam, dan rasa manis yang dipandangnya cukup diterima di pasar karena selera pembeli berbeda-beda. Pemasaran produk ini dilakukannya dengan cara menitipkan ke bakul maupun menjual konsumen langsung menurutnya tidak menjadi kendala dalam proses pemasaran. Selanjutnya, dijelaskannya bagaimana teknis pembuatan aneka rasa emping melinjo. Penjelasan dilakukan sesuai dengan jenis produk yang dihasilkan yaitu emping melinjo rasa asin, rasa manis, dan rasa manis-asam secara detail mulai dari persiapan, pemilihan alat, cara membuat bumbu, proses pembuatan, proses pengeringan dan pengemasan. Pada proses ini, warga belajar memperhatikan penjelasan praktisi, mencatat hal-hal yang penting seperti nama bahan, ukuran bahan, waktu pembuatan, dsb., dan bertanya kepada praktisi seperti bahan yang sulit diperoleh apakah dapat diganti dengan bahan yang lain. Tanggapan positif dan memuaskan diberikan oleh praktisi terhadap pernyataan atau pertanyaan warga belajar secara komunikatif dan terkadang berbahasa local (jawa).

Pembelajaran praktik pembuatan diversitifikasi olahan emping melinjo bertujuan untuk memberikan keterampilan dalam memproduksi emping aneka rasa yang memiliki harga jual tinggi. Dengan terlebih dahulu meminta warga belajar untuk memperhaitkan, proses pembelajaran dilakukan dengan memberikan penjelasan mengenai ukuran dan nama bahan yang 


\section{Diklus: Jurnal Pendidikan Luar Sekolah, 2 (3), September 2019 - 79 \\ Entoh Tohani, Hiryanto, RB. Suharta, Iis Prasetyo}

dibutuhkan. Selanjutnya, praktisi dibantu dengan asistennya memberi contoh bagaimana membuat tiga jenis olahan emping aneka rasa secara bergantian. Warga belajar memperhatikan apa yang dilakukan oleh praktisi mulai dari mencampur bahan, menyiapkan alat, mencampur emping dan bumbu, meniriskan emping yang dicampur bumbu, dan menjemurnya. Dalam proses ini, praktisi memberikan kiat-kiat atau taktik yang menjamin proses pembuatan dapat efesien dan efektif misalnya memberikan tip mengangkat emping yang sudah dibumbu secara tepat tanpa merusak emping. Warga belajar pun memberikan perhatian besar dalam pembelajaran ini dengan bertanya misalnya media aman apa yang dapat menggantikan tempat penjemuran emping aneka rasa yang mudah didapat, dan bagaimana mempertimbangkan tingkat kepedasan dari emping rasa pedas. Setelah dengan pendampingan langsung, warga belajar melakukan proses pembuatan secara mandiri dan berkelompok. Praktik pembelajaran ini pun dilakukan kelompok sasaran sampai dengan menghasilkan produk emping aneka rasa yang siap konsumsi.

Kegiatan pembelajaran selanjutnya adalah penugasan kepada kelompok sasaran. Mereka diharapkan dalam memiliki keterampilan aplikatif bagaimana memproduksi dan memasarkan olahan emping aneka rasa yang dihasilkan kelompok. Warga belajar praktik memproduksi secara berkelompok emping aneka rasa yang dihasilkan. Pengerjaan praktik pembuatan emping aneka rasa dilakukan di masing-masing kelompok kecil yang sebelumnya sudah terbentuk. Pelaksanaan praktik menyesuaikan waktu yang disepakati masing-masing kelompok kecil. Untuk memperlancar kegiatan pembelajaran ini, pemovitasian dilakukan peneliti dengan cara memberikan stimulus bantuan dana untuk membeli bahan-bahan yang dibutuhkan dan menyediakan kesempatan kepada kepada kelompok sasaran untuk berkomunikasi dengan pengembang melalui media sosial atau telepon.

\section{Refleksi}

Untuk menjamin pelaksanaan pembelajaran diversifikasi produk olahan bagi perempuan pengrajin emping melinjo berhasil dilakukan evaluasi terhadapnya baik proses maupun hasil. Evaluasi proses dilakukan dengan pengamatan terhadap aktivitas belajar peserta pelatihan. Hasil pengamatan menunjukkan bahwa para peserta cukup antusias mengikuti kegiatan pembelajaran. Hal ini nampak dari suasana pembelajaran yang menyenangkan seperti dalam diskusi dalam pembelajaran teori oleh praktisi dan pembelajaran praktik yang mana warga belajar dari bertanya kepada praktisi dan asistennya, saling membantuk dalam proses belajar praktik, dan bergiliran merasakan praktik pembuatan olahan emping dalam suasana hangat, terdapat selingan-selingan perkataan yang menghibur, dan sikap memperhatikan apa yang dijelaskan oleh narasumber.

Evaluasi terhadap hasil pelatihan dilakukan dengan menelaah hasil kerja peserta dan melakukan wawancara individual maupun diskusi bersama mengenai penguasaan pengetahuan dan keterampilan dalam pengolahan emping yang berdaya jual tinggi. Hasil pengumpulan data menunjukkan bahwa kelompok sasaran memiliki kesadaran kelompok sasaran untuk menghasikan produk ekonomi yang inovatif untuk meningkatkan produktivitas usaha seperti yang diungkapkan oleh ketua kelompok kecil bagian selatan yang mengatakan "telah merasa tahu kalau emping dapat diolah menjadi produk yang berasa". Warga belajar pun dapat memperoleh pemahaman produksi produk olahan yang beragam dalam memanfaatkan potensi lokal, dan memiliki keterampilan kelompok sasaran dalam memproduksi beragam produk ekonomis berbasis potensi local. Kedua hal ini terungkap dari pertanyaan ketua kelompok besar yang menyatakan "pembelajaran yan dilakukan memberikan keterampilan baru, awalnya mereka tidak paham membuat olahan emping sekarang menjadi bias, harapan kami usaha kelompok dapat maju”.

Peningkatan hasil belajar pun ditunjukkan dengan kemampuan warga 


\section{Diklus: Jurnal Pendidikan Luar Sekolah, 2 (3), September 2019 - 80}

Entoh Tohani, Hiryanto, RB. Suharta, Iis Prasetyo

belajar dalam memproduksi olahan emping aneka rasa. Hasil produk yang dihasilkan pada saat pembelajaran praktik menurut praktisi sudah dapat dipandang memuaskan baik dalam bentuk dan warna maupun dalam hal rasa. Begitu pula, hasil penugasan menunjukkan mereka mampu memproduksi emping aneka rasa yang siap dijual. Namun demikian, produk yang dihasilkan belum dapat dipasarkan secara intensif kepada masyarakat sehingga produk olahan ini belum dapat memberikan penghasilan yang lebih besar kepada kelompok sasaran. Hal ini disebabkan kelompok sasaran belum memiliki kemampuan pemasaran yang tepat dan adanya kesibukan kelompok sasaran yang mengganggu proses produksi olahan emping.

Pelatihan diversifikasi produk berbasis potensi local bagi kaum perempuan merupakan suatu cara mengembangkan kualitas perempuan agar dapat memiliki keterampilan dalam memecahkan masalah khususnya ekonomi yang dihadapi individu maupun kelompok. Sebagai bentuk tindakan edukatif, pelatihan ini didesain dengan mempertimbangkan berbagai factor yang mempengaruhi pencapaian keberhasilannya. Salah satunya adalah pemahaman kebutuhan pelatihan yang sesuai dengan karakteristik kelompok sasasaran. Pemahaman ini harus dilakukan secara objektif dan mendasarkan pada informasi yang valid sehingga terhindar dari pemhaman kebutuhan yang semua. Kebutuhan yang objektif menjadi arahan tindakan pendidiakn dilakukan dengan terencana dan memotivasi kelompok sasaran untuk terlibat dalam proses pelatihan. Terkait dengan ini, hasil pengembangan menunjukkan pemahaman kebutuhan dilakukan secara baik dengan cara melibatkan kelompok sasara untuk mengkaji dan mengenai kebutuhan pendidikan yang dipandang perlu segera dipenuhi.

Proses pelatihan pun sebaiknya dilakukan dengan menekankan pada partisipasi warga belajar. Adanya partisipasi mereka baik dalam perencanaan, pelaksanaan, dan penilaian kegiatan pelatihan menunjukkan suatu intensitas yang baik untuk merubah perilaku menjadi perilaku yang memiliki sikap positif, berpengetahuan, dan terampil. Proses pelatihan yang dilakukan terhadap kelompok dipandang berjalan melibatkan partisipasi kelompok sasaran. Mereka terlibat dalam penentuan program belajar, proses pembelajaran, dan pemanfaatan hasil belajar. Keterlibatan mereka dimotivasi keinginan untuk meningkatkan kualitas kehidupan mereka sendiri dengan memanfaatkan potensi local yang tersedia. Selain itu, interaksi positif antara kelompok sasaran dengan pengembang menjadi media partisipasi mereka dapat terwujud. Interaksi ini diwujudkan dalam perilaku komunikatif, bersahabat, dan memposisikan kelompok sasaran sebagai mitra dalam mengembangkan masyarakat. Dalam hal ini, warga belajar diposisikan sebagai subjek pemberdayaan.

Hasil belajar pelatihan yang diselenggarakan menunjukkan adanya perubahan perilaku warga belajar yang positif dalam bentuk tumbuh kesadaran terhadapa masalah yang dihadapi, penguasaan pengetahuan, dan keterampilan dalam memproduksi aneka olahan berbasis potensi local. Perubahan perilaku ini menunjukkan adanya hasil yang diharapkan dari pelatihan sebagaimana dirumuskan sejak perencanaan pelatihan. Namun demikian, hasil belajar idealnya tidak sebagai pada tataran output pendidikan tetapi perlu harus sampai pembentukan outcomenya seperti peningkatan kesejahteraan individu maupun masyarakat, peningkatan layanan pendidikan lain, peningkatan lapangan kerja baru, dsb. Oleh karenanya, outcome pelatihan harus dijamin agar terjadi dengan melakukan tindakan edukatif lain seperti pemberian motivasi kepada kelompok sasaran, penyediaan layanan konsultasi bisnis, pendampingan manajemen usaha, dsb. Tentu hal ini semua dapat dilakukan apabila pengembangan memiliki kompetensi pemberdayaan yang optimal dan didukung ketersediaan sumber daya.

\section{SIMPULAN}

Mendasarkan pada hasil kegiatan dan pembahasan dapat disimpulkan bahwa kegiatan pelatihan yang dilakukan dapat 
memberikan hasil belajar yang positif terhadap warga belajar yang mencakup: warga belajar memiliki kesadaran untuk mendiversifikasi produk berbasis potensi local, memahami konsep inovasi pengolahan olahan produk berbasis potensi local, memiliki keterampilan dalam memproduksi dan mendiversifikasi produk olahan berbasis potensi local untuk menghasilkan pendapatan yang lebih besar dalam konteks pemberdayaan masyarakat walau masih perlu dioptimalkan. Oleh karenanya, diperlukan suatu tindakan pelatihan lain yang memungkinkan kelompok sasaran dapat menerapkan sikap, pengetahuan, dan keterampilan manajemen usaha berbasis potensi local agar pembelajaran berdampak besar dan optimal. Beberapa saran yang dapat dikemukakan adalah (a) warga belajar perlu lebih berkomitmen dalam melaksanakan fungsi dan perannya dalam memproduksi olahan berbasis potensi local guna memberdayakan masyarakat, (b) warga belajar perlu segera mengimplementasikan pemikiran inovatif yang dihasilkan dalam pembelajaran yang telah dilaksanakan, (c) fakultas perlu memfasilitasi optimal bagi berbagai pelatihan berbasis masyarakat sebagai wujud tri dharma PT yang diembannya, dan (c) perlu pengembangan kemampuan pemasaran yang lebih bermakna dengan melibatkan berbagai tindakan pemberdayaan yang lebih intensif. .

\section{DAFTAR PUSTAKA}

Baron, Angela \& Amstrong, Michae. (2007). Human Capital Management. Philadelphia: Kogan Page

Ife, Jim. (1997). Community development: Creating community alternativesvision, analysis and practice. Melbourne: Longman.
Illeris, Knud. 2009. Contemporary Theories of Learning : Learning Theorists. New York: Taylor \& Francis Routledge

Knowless, M.S., Holton III, E. F., \& Swanson, R.A. (2005). The adult learner: The definitive classic in adult education and human resource development. Burlingtong: Elsevier.

Korten, David C. (1986). Community management: Asian experiences and perspectives. West Hartford C.: Kumarian Press.

Merriam, B. Sharan. \& Brockett, Ralph G. (2007). The Profession and Practice of Adult Education. San Francisco: John Wiley \& Sons, Inc.

McIntyre, A. (2007). Participatory action research (Vol. 52). Sage Publications.

Müller, Eduard., Apprleton, Michael., Ricci, Glenn, Valverde, Allan., Reynolds, David W. (2015). Capacity Development. Dalam Protected Area Governance and Management, oleh Graeme L. Worboys, Michael Lockwood, Ashish Kothari, Sue Feary, Ian Pulsford. Annu Press. Diakses dari https://www.jstor.org/stable/j.ctt16 57v5d.16

Narayan, Deepa. (ed). (2002). Empowerment and poverty reduction: $A$ sourcebook. Washington, DC. : The World Bank.

BPS Kabupaten Kulon Progo. (2018). Kecamatan Kokap Dalam Angka 2018. Wates: PT. Solo Grafika Utama 